\title{
EAl Endorsed Transactions

\section{OBE: Perception of Computer Science Learners and Teachers in online learning during COVID-19}

\author{
Basetty Mallikarjuna $^{1 *}$, Munish Sabharwal ${ }^{2}$, Pardeep Kumar ${ }^{3}$ and Niranjanamurthy $\mathrm{M}^{4}$ \\ ${ }^{1}$ Associate Professor, SCSE, Galgotias University, Greater Noida, GauthamBudhNagar, Uttar Pradesh, India 203201. \\ 2 Dean of SCSE, Galgotias University, Greater Noida, GauthamBudhNagar, Uttar Pradesh, India 203201. \\ ${ }^{3}$ Pro-Vice Chancellor, Galgotias University, Greater Noida, GauthamBudhNagar, Uttar Pradesh, India 203201. \\ ${ }^{4}$ Assistant Professor, Department of Computer Applications, M S Ramaiah Institute of Technology (Affiliated to \\ Visvesvaraya Technological University, Karnataka), Bangalore, India 560054.
}

\section{Abstract}

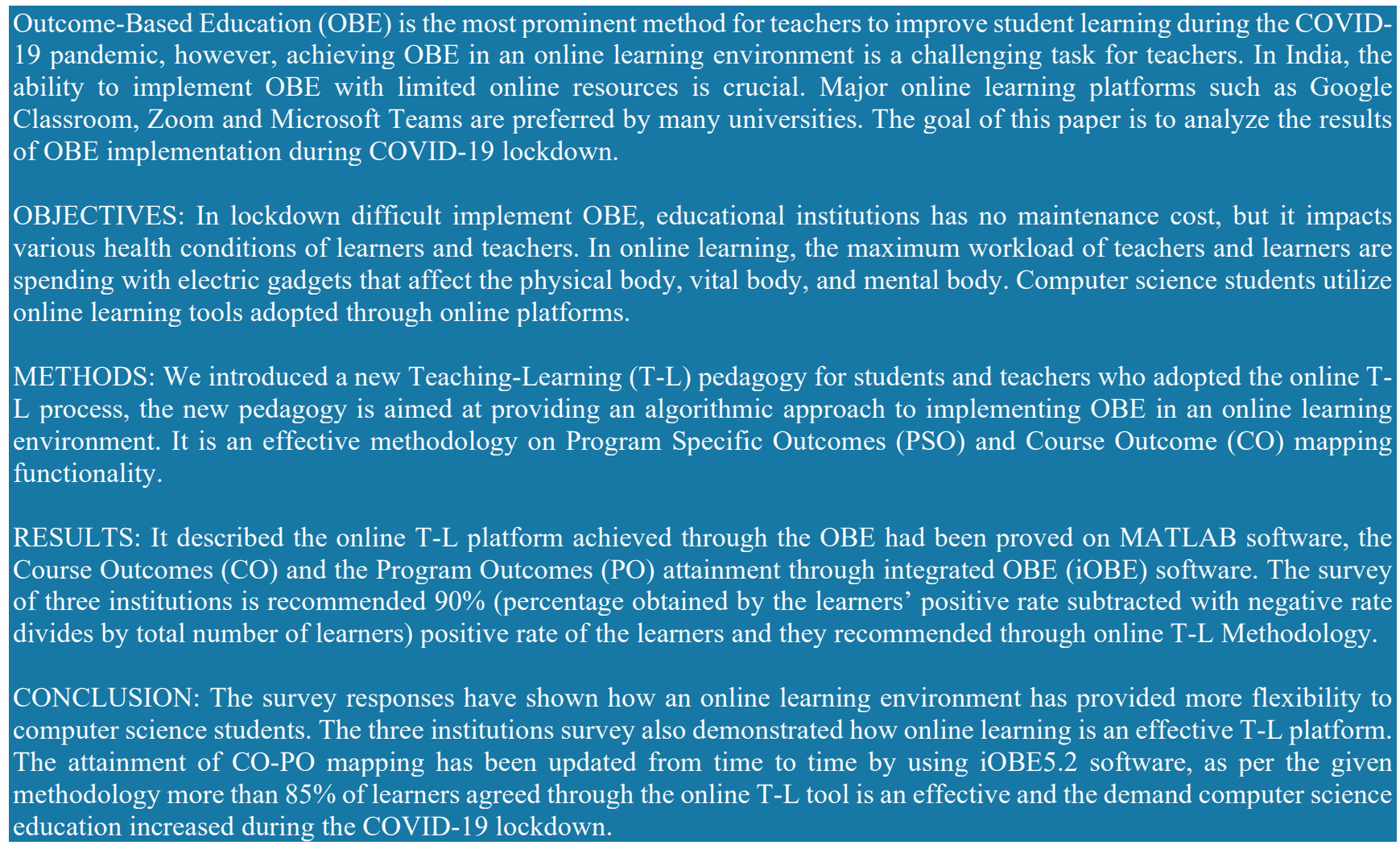

Keywords: OBE, online learning, Computer Science, Course Outcomes, Programme Outcomes, iOBE.

Received on 11 June 2021, accepted on 08 November 2021, published on 12 November 2021

Copyright (C) 2021 Basetty Mallikarjuna et al., licensed to EAI. This is an open access article distributed under the terms of the Creative Commons Attribution license, which permits unlimited use, distribution and reproduction in any medium so long as the original work is properly cited.

doi: 10.4108/eai.12-11-2021.172105

"Corresponding author. Email: basetty.mallikarjuna@galgotiasuniversity.edu.in 


\section{Introduction}

Popular online learning platforms (Microsoft Teams, Google Classroom, and Zoom) for computer science engineering [1] and normal degree undergraduate (UG) students are a beneficial tool, but $\mathrm{KG}$ and school students feeling difficulty for accessing the online resources [2]. Online learning for computer science students allows them to extend their knowledge with new flexibility granted by online resources [3]. There is a huge difference in how online resources have been utilized before the lock and after the lockdown [4]. Online teaching is slowly gaining popularity due to its design, visuals, and quality of platform it establishes between the student and teachers. T-L tools helps computer science students to understand concepts and boost collaboration between in student-teacher interactions. The curriculum for students needs to change during the COVID-19 pandemic, the quality of curriculum required to match and easy way of explain the teachers by using online resources [5]. The best way of education can be equipped with the offline classes through the personal interaction and preparation of learners and mentorship provides the quality learning, the same can be incorporated by the online learning to attain the OBE. While different professors have different teaching styles, online learning is consistent and standardized for students, so a student can look through many different professors on YouTube to help them learn a concept[7]. More than 600 million internet connotations are increased during COVID-19 pandemic [6]. The huge number of options for students to grasp the concepts of online course providers with paid or free basis such as NPTEL, edX, Udacity, Berkely, Coursera, Udemy, Alison, Oracle Academy, and Microsoft [8].

Any concept in the course is expected to reach the goal to satisfy the course objectives and course outcomes should must as per OBE [9]. There is no exact T-L methodology proposed by any researchers to attain OBE [10]. Especially in a Computer Science curriculum that is undergoing significant changes to adapt to online learning. The following tools listed are used for online learning and are associated with OBE [11].

Table 1. Popular online T-L platforms [11].

\begin{tabular}{|l|l|}
\hline Online T-L tool & \multicolumn{1}{|c|}{ Activities } \\
\hline & $\begin{array}{l}\text { Outstanding T-L tool establish } \\
\text { between the learners and teachers, } \\
\text { sending content material through } \\
\text { chatting and messaging. It is } \\
\text { integrating with google apps. The host } \\
\text { can accept up to 250 users to connect } \\
\text { with laptop or mobile phones at } \\
\text { particular instance of time. The } \\
\text { recoding and screen sharing are two } \\
\text { most flexible options to the users, }\end{array}$ \\
\hline
\end{tabular}

\begin{tabular}{|l|l|}
\hline \multirow{7}{*}{ Microsoft Teams } & $\begin{array}{l}\text { automatic text to speech option } \\
\text { available. The disadvantage has no } \\
\text { waiting room for the users who joined } \\
\text { at early, participants privacy needed } \\
\text { to be improved. }\end{array}$ \\
\hline $\begin{array}{l}\text { Most of the universities started online } \\
\text { T-L process with Microsoft Teams, it } \\
\text { is collaborated with Office 365, } \\
\text { recording and screen share are two } \\
\text { most flexible options to the users. The } \\
\text { major advatage invite the participant } \\
\text { through sending the calls, there is no } \\
\text { time limit for the meeting, the } \\
\text { participant joins through meeting } \\
\text { early. The disadvantage has no } \\
\text { aaiting room for the participant, } \\
\text { learners feel difficulty to submit the } \\
\text { assessments and conduct the } \\
\text { assessments for the teachers }\end{array}$ \\
$\begin{array}{l}\text { Due to COVID-19 pandemic, it has a } \\
\text { great demand to conduct the remote } \\
\text { meetings and online classes and most } \\
\text { useful access mobile and laptop, } \\
\text { needs less amount of network } \\
\text { bandwidth, free google account to } \\
\text { login with google id. The } \\
\text { disadvantage has lots of security } \\
\text { issues facing while meetings, the } \\
\text { maximum 40 minutes to avail the } \\
\text { meeting. }\end{array}$ \\
\hline ZOOM
\end{tabular}

The major online T-L platforms listed in Table 1, combined with the help of tools like MS Word, PowerPoint, Libre Office, and Google Drive can together create an environment that helps boost the learning objectives of the students. These online platforms can be used to enhance the modern education system and solve contemporary issues for educators [12]. The WordPress, Drupal is one such popular learning resource, IIT Bombay India developed A-VIEW online software for MOODLE and provided the Faculty Development Programmes (FDP) [13]. Camstudio video making software to make the video lectures, GeeksforGeeks popular website for learning and most useful for learners, not only for computer science learners and other branches like ECE, EEE, Civil and Mechanical engineering learners. The teachers uploaded their lecture videos to YouTube and provide the YouTube links and material to the students pursuing UG, PG, and scholars. High school learners utilised popular YouTube channels like Khan Academy [14]. The objective of an online course in computer science described as follows [15]:

i. To study the theorical subjects

ii. To study the programming subjects

Theoretical courses refer to classes on computer networks, database management, and advanced courses like blockchain technology, artificial intelligence etc. the programming 
courses, meanwhile, refer to classes teaching a language such as Python, $\mathrm{C}, \mathrm{C}++$, and JAVA. The online teaching of every course in computer science related with programming courses $[1,16]$. The students analyse information learned in a theoretical session with a corresponding practical session. In India, most of universities offer courses in computer science. The teaching faculty makes the lecture slides, assessments, and inform students about the content they uploaded. The students download the material in the format of PDF file, PowerPoint, and word file. The students also participate in discussions on an online dashboard [8]. The setting of online education improves the psychological component of learning for the students, allowing the teacher to make needed updates to content at any time, and by making learning accessible through the mobile phones and laptops, students can access the contents anytime, anywhere, any number of times. The learning environment creates quality and quantity in between the teacher and learner. The quality of the teaching establishes between the teacher and learner [9]. In the coming years chatbots can be used to teach computer science subjects and programming languages, the robots already started projectbased and inquiry-based teaching as STEM approach, means the common subjects of Science, Technology, Engineering and Management to inspire the leaners. Online learning provides an open platform in computer science where students can learn programming, theory, and conduct research projects [10]. Online T-L tools are open software platform where possible to effective manner to teach in computer science domain [11]. There are numerous options available in E-learning today, however, particularly in computer science and engineering learners, Moodle is an effective platform to learn theory and practical courses [12].

The remaining structure of the paper is organized as follows, section 2 provides the related work with objectives, section 3 discussed the methodologies, section 4 elaborates the results and discussion, and section 5 concludes the paper followed by references.

\section{Related Work}

According to the survey [16-19], before lockdown offline teaching techniques provided theoretical knowledge rather than practical knowledge, as students are passive learners and simply memorize the concepts inside the classroom [13]. During lockdown, the teacher instructs as well as deliver contents for every learner to follow, the teacher is more active than the learner, the teacher is also sentimental in nature in the online meeting, not questioned and every learner follows his lecture [14]. The survey [20-25] describes the comparison of teacher performance as evaluated by students before and during lockdowns.
Table 2. Comparison of the performance of teacher between the before lockdown and after lockdown.

\begin{tabular}{|l|l|l|l|l|}
\hline Survey Question & \multicolumn{2}{l|}{$\begin{array}{l}\text { Before } \\
\text { COVID-19 }\end{array}$} & \multicolumn{2}{l|}{$\begin{array}{l}\text { After COVID- } \\
\text { COtal teachers 167 }\end{array}$} \\
\hline \multicolumn{2}{|l|}{$\begin{array}{l}\text { OUTC } \\
\text { OME }\end{array}$} & $\begin{array}{l}\text { OUTC } \\
\text { OME }\end{array}$ \\
\hline Learning Material & 21 & No & 121 & YES \\
\hline Video Material & 35 & No & 134 & YES \\
\hline Live lectures & 15 & No & 145 & YES \\
\hline Discussion Forum & 10 & No & 153 & YES \\
\hline Virtual Sessions & 15 & No & 148 & YES \\
\hline Self-Assessments & 23 & No & 146 & YES \\
\hline $\begin{array}{l}\text { Concept wise course } \\
\text { material }\end{array}$ & 16 & No & 149 & YES \\
\hline Periodic test & 28 & No & 142 & YES \\
\hline Final Examination & 14 & No & 151 & YES \\
\hline
\end{tabular}

As per the Table 2, the performance of the teachers $80 \%$ positive rate of the teacher treated as the outcome 'Yes', to improved OBE the teachers can send online material like animated videos, photos, text messages, and any type of materials through the online platforms. The workload of the teachers increases by $85 \%$ during the lockdown [15].

\subsection{The importance of Flipped classroom in Online Learning}

The flipped classroom relies on online learning, in online learning instructor delivers the content with excitement but doesn't know how many of his learners actually attentive, flipped class room engaged learning methodology during the lockdown as shown in Figure 1 [16]. In an online environment students switch of their audio and video, resulting in removing them from any class interaction. As per the flipped classroom methodology, students watch 10-15 minutes video after the live lecture and are given exercises in the interactive section [17]. The instructor delivers an instructional content through online, the learners go through this online content outside of the meeting from wherever they are and learners perform the activities related to the online content inside the classroom. In online learning focuses on higher domain knowledge levels like apply, analyze, create, rather than on lower domain knowledge levels like understand, remember [18].

The teacher upload the lecture videos to YouTube, creating a flipped class room methodology, as students watch videos and form an in-depth learning outside of class with personalized discussions with their fellow learning members occurring in the online class [19]. The learning environment becomes effective with engaging relevant, authentic, fun, peer based, technical involvement, project-based learning, making real-world connections, using physical movement, student choice and using visuals. 


\subsection{Impact of Social Life}

Online learning reduces maintenance cost and electric supply of schools and universities, and also reduces the travelling cost and time of students and teachers. National Wildlife Foundation (NFW) states that online learning reduces the quantity of the paper and crude oil used in education [20]. The student registrations, approval registration, admission, curriculum development representing a huge amount of the paper usage. $60 \%$ of paper used by educational institutions was wasted, with one tone paper taking 16 trees to produce, and the 10 tons of paper being equal to a hundred barrels of crude oil [21].

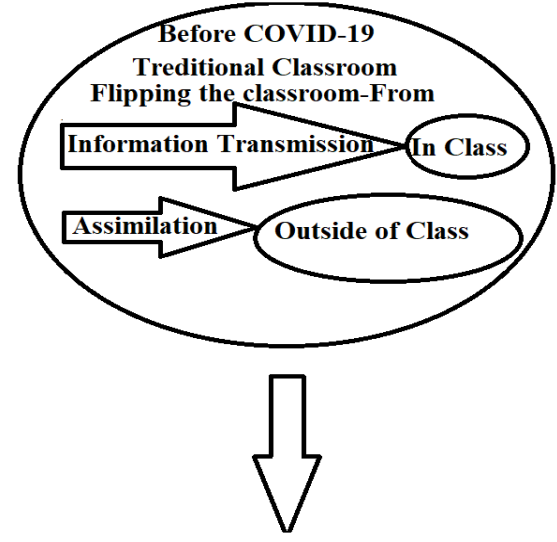

Flipped classroom
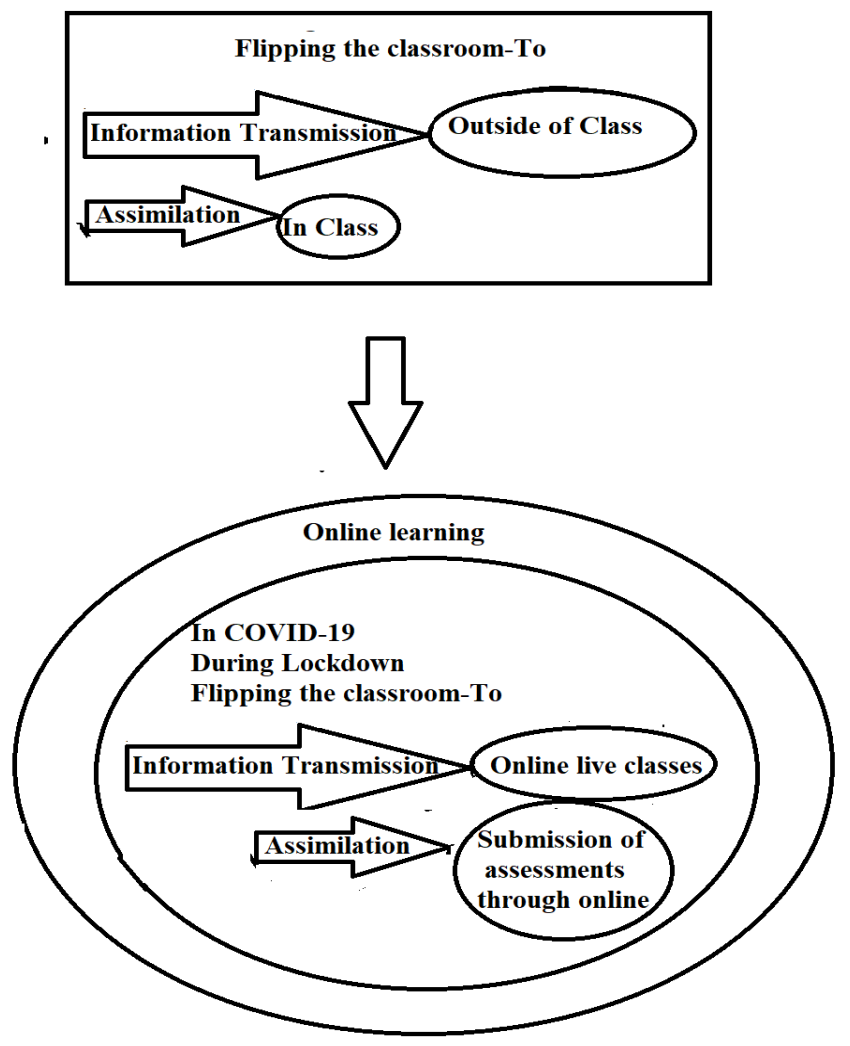

Figure 1. Flipped class room during lockdown
It reducing the carbon emission, if 100 students did not travel to school the carbon dioxide reduces to $10 \%$, online learning reduces the carbon emission for students and teachers to travel the university, as per the study if $10 \%$ of carbon dioxide reduced then 350 million printer cartridges saved this year as per the literature during the COVID-19 lock down [22]. There is also an impact on the physical and mental health of students, the study says that online learning not only reduces the academic achievement of students, but also correlates with increased sleepless depression from continuously watching the laptop and mobile phone 6 to 8 hours per a day $[23,43]$. Students and teachers are also suffering from increased backbone pain and neck muscle pain, as well as gastric disorders, the gastric disorders from eating meal without physical movement leading to indigestion and stomach bloating [24,34], while continuously watching laptop/mobile phones due to the depression of assignments submission and excess gas released from the stomach bloating and too much burning pain from the chest pain from upper-chest, lower-chest, and middle part of the chest [24]. Due to oversitting of electronic gadgets, it great effect of mortality rate, eyestrain is a common disease in online learning watching much time to the laptop and mobile device [25].

\subsection{The demand of job opportunities}

The demand of for computer science professionals increased during COVID-19 lockdown throughout the world [26]. Employment for computer science learners wants to find the job in top industries, hence they need to get admission in computer science to the top reputed universities, computer science learners are not only interested to join for placements but also to gain actual knowledge of computer science [27]. Top international university targets $85-95 \%$ placements for all computer science students [28]. The demand for computer science professionals and number of students can be seen in Figure 4. as per the data from the U.S. Bureau of Labor Statistics[29].

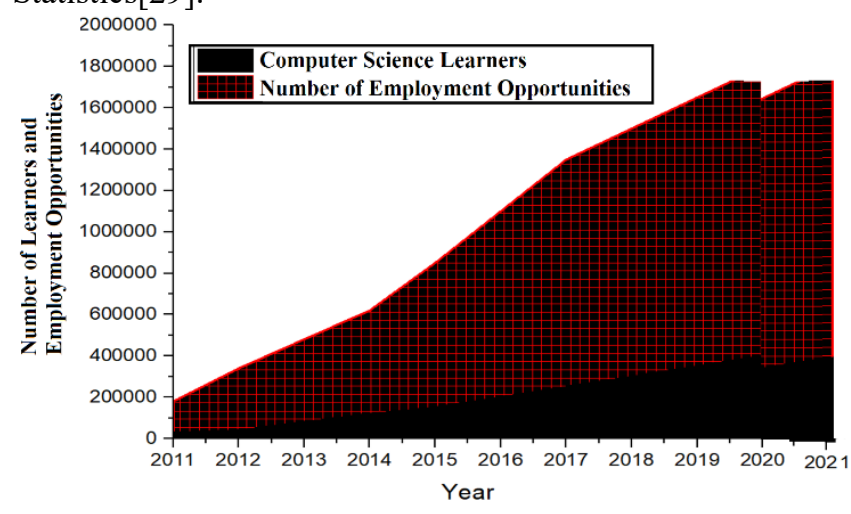

Figure 2. Demand of Computer Science 
The IT industry recruit engineers during lockdown and increases the number projects and looking for in-depth programming knowledge in computer science, not only from the computer Science and IT branch in engineering, however other branches like Electrical, Electronics, and Mechanical studies [30]. The growth of demand for computer science education in the USA and Canada has been rapid, boosted by the invention of Blockchain Technology, Cyber Security, Robotics, and Artificial Intelligence [31].

OBE in 2020 and 2021 accreditation or recognition through Washington accord postponed of Tier 1 engineering instituions, integrated the CO-PO attainment to a large extent, an OBE in COVID-19 lockdown the survey collected from the passed-out students from the institution, stakeholders [32], alumni of the respective institution, survey of the placements. Course outcome is the expected result after completion of the course and is used as a basis to design the curriculum to achieve the expected outcome [33]. An OBE in COVID-19 doesn't follow a strict guideline for any course; it relies on individual understanding and need of student's what goals to be set and how to achieve those goals [35]. This paper proposed students adopt an online T-L process. OBE for computer science learners is the experimental model rather than theory. In USA most of the top universities such as Stanford, Pennsylvania, MIT, Harvard, and Washington stated that OBE is a part of their curriculum.

The CO-PO mapping matrix calculation to use iOBE 5.2 software which can run on Matlab2016b as executable files with GUI. The resultant CO-PO matrix obtained with the iOBE software. This paper also proposed and received positive response to the online learning of the conducted survey during lockdown.

\section{Proposed Methodology}

To combat the spread of COVID-19 the Indian government decided to implement lockdown measures on March 23st 2020 [36], the lockdown was strictly implemented by schools, colleges and educational institutions, and all residential students went back to their homes, the lock down extended to various stages, the positive cases are extended by various regions of the country [37]. All educational institutions were rendered completely dependent on online learning tools like Microsoft teams, Google meets, and Zoom. The Indian government created many online learning platforms such as SWAYAM a massive online resource aimed at engineering students, diploma learners, NITTTR started Ulektz, it is useful to faculty to apply STTPs and FDPs [38]. Schools started online learning by using DIKSHA Digital Infrastructure, an initiative of the National Council of Educational Research and Training (Ministry of Education, Govt of India) for school education, the curriculum of every class as per the NCERT, CBSE, NIOS provide online learning [39].

Online learning in computer science allows students to learn computer science anywhere and anytime [40]. The learners learning for the computer science subjects $\mathrm{C}, \mathrm{C}++$, JAVA possible with social media and content interactions, using personal devices (MP3 players, notebooks, smart phones, and tablets etc). The leaners are willing to adopt online education associated with classroom learning by conducting survey in various educational institutions [41]. As per the survey [26-30] the students had internet connections, access to a mobile or a laptop, knowledge of how to operate a mobile phone or personal digital device, understood the default language of the platform, and the educational institutions followed the unique Algorithm 1 described as follows [42].

\section{Algorithm 1: Learners adopted Online Teaching- Learning Process}

Step 1: The academic institutions started with the 'iCloud EMS, it is a cloud based management system, helps to educational institutions, to create lecture materials, maintain the student attendance and staff profiles, and academic transactions like course plan and session plan etc. This management system is a high-performance, userfriendly, and scalable for faculty to manage the learners, this is also used for student registration [43], attendance management, as per the syllabus definition prepared by the course breakups to upload, it is easy to access as shown in Figure 3.

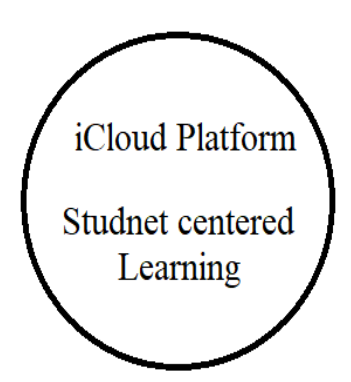

Figure 3. Process of iCloud management.

Step2: In addition to iCloud management, the teaching learning process established by the Microsoft Teams/Zoom/Google meets to create an environment of teaching learning process. The computer science learners predicted the quality of teaching achieved through the following sub steps [44].

Step 2a: Set the class through the calendar and provide information to the learners.

Step 2b: Learners join the meeting as per the timing.

Step 2c: Teachers interact with learners through the online platform.

Step 2d: Teachers allotted the assessments through assignment section.

Step 2e: Generate performance of the learners 


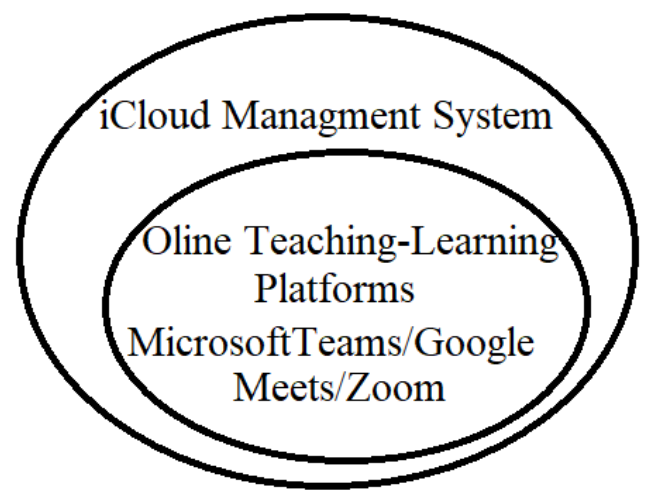

Figure 4. Software tools for Online learning

Step 3. The end of the semester to conduct the examinations through the Learning Management System (LMS), it is an online framework to build for the learners to perform the assessments and decides as per the grading system. Learners can possible to watch the video in LMS through the offline, after watching the video learners can perform the assessments, the method of teaching process provides that peer-to-peer teaching [45]. Learners can obtained the notifications when the video lectures are uploaded.

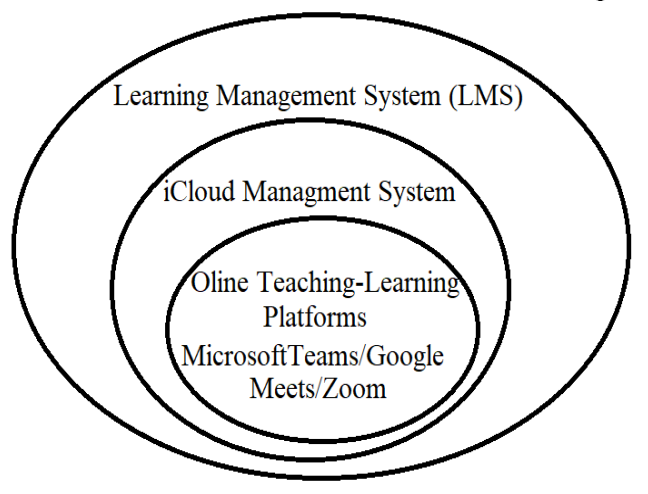

Figure 5. Learners adopted Online T-L Process

Step 4: Repeat the steps 1, 2 and 3 throughout curriculum.

The CO and PO process establish through OBE, every $\mathrm{CO}$ should be mapped to a PO and balance the cognitive and metacognitive domains. The Evaluation of T-L process as follows

- Obtaining of feedback from learners through the online.

- Improve the learners adopted online T-L process

Based on the survey of the learners update the T-L process. As per Algorithm 1, the adopted T-L process is shown in Figure 6.

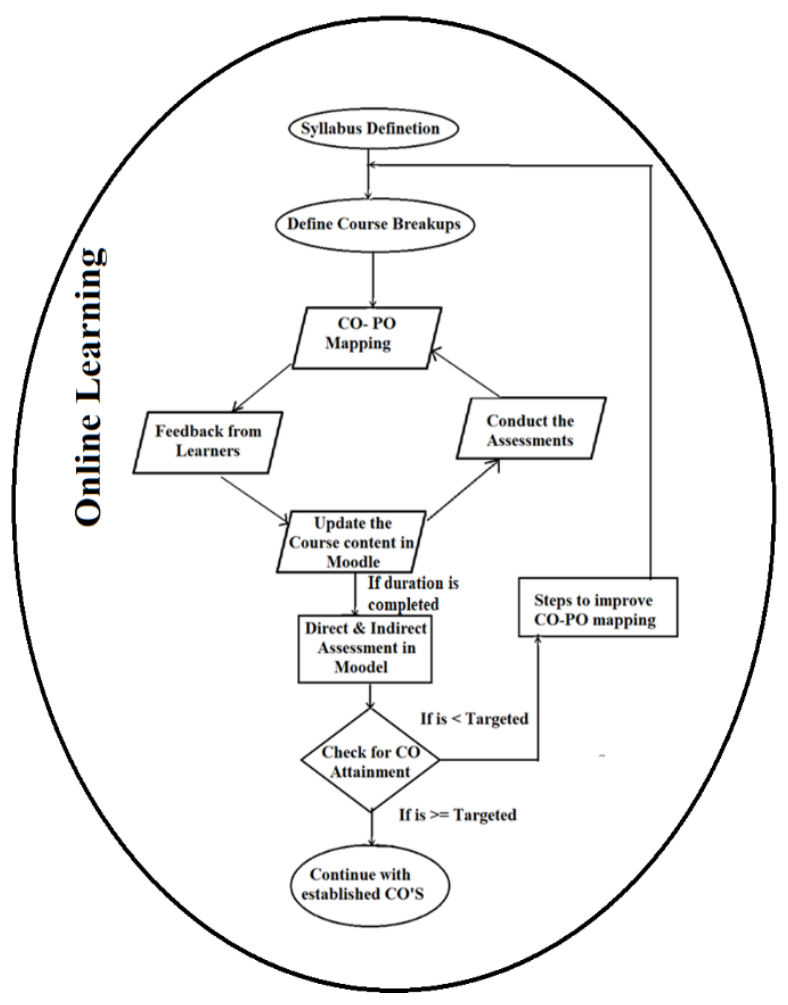

Figure 6. Learners adopted Online T-L Process with CO-PO attainment in OBE

The proposed T-L pedagogy improves the overall aspects of online learning. The following Table 4 is comparison of OBE before COVID-19 lockdown after COVID-19 lockdown [46]. The proposed T-L pedagogy has advanced features and will be able to extend learning outcomes of students in lockdown by making the course more practical rather than theoretical. The following are the issues are faced by current pedagogy [47]

i. Race of Grades: In online learning platforms construction of grade of learners through the assessments, obtain the learner from his curriculum, the OBE has always improved the performance of learners. It depends up on the knowledge of the learners.

ii. Creative and Innovative Thinking: In online learning, creative teaching is most necessary, and it is developed to the critical thinking of learners. They can learn creatively and become inventors of their future.

iii. Single way conversation: Before lockdown off line classroom learning provides one way of conversation, the teacher interacts offline, the learners are active in this dialogue. OBE provides the two ways of conversation but the learner can be an active participant.

iv. Lack of self-study in pedagogy: It lacks of self-study in offline class room teaching. Online teaching depends upon self-study of pedagogy. In OBE most of the selfstudy has been built by the learner, in this process the skills of learner has been improved and creative and innovative thinking has been shaped, and eventually the 
learner has earned the expected grade. The following Table 3 shows the online T-L pedagogy process.

Table 3. Online teaching pedagogy before and after lockdown [48].

\begin{tabular}{|c|l|c|}
\hline Issue & $\begin{array}{c}\text { Before COVID-19 } \\
\text { lockdown T-L Process }\end{array}$ & $\begin{array}{c}\text { Online teaching } \\
\text { through OBE }\end{array}$ \\
\hline $\begin{array}{c}\text { Race of } \\
\text { Grade }\end{array}$ & $\begin{array}{l}\text { Learner cannot able to } \\
\text { determine his } \\
\text { performance through } \\
\text { offline teaching }\end{array}$ & $\begin{array}{c}\text { The assessments } \\
\text { of grades show the } \\
\text { improvement learner } \\
\text { further study. }\end{array}$ \\
\hline $\begin{array}{c}\text { Creative } \\
\text { and } \\
\text { innovative } \\
\text { thinking }\end{array}$ & $\begin{array}{l}\text { Implementing and } \\
\text { practicing concept } \\
\text { creative and } \\
\text { innovative thinking } \\
\text { can be developed }\end{array}$ & $\begin{array}{c}\text { Demonstrational } \\
\text { video applications, } \\
\text { self-doing exercises, } \\
\text { virtual session and } \\
\text { discussion forum }\end{array}$ \\
\hline $\begin{array}{c}\text { Single } \\
\text { way } \\
\text { of } \\
\text { conversation }\end{array}$ & $\begin{array}{l}\text { In offline class } \\
\text { room teaching } \\
\text { Conversation between } \\
\text { the Implementation \& } \\
\text { Practicing the concepts } \\
\text { are single way of } \\
\text { conversation }\end{array}$ & $\begin{array}{l}\text { Demonstrational } \\
\text { video of application, } \\
\text { self-doing exercise, } \\
\text { virtual session } \\
\text { discussion forum }\end{array}$ \\
\hline $\begin{array}{c}\text { Lack of } \\
\text { Self Study }\end{array}$ & $\begin{array}{l}\text { Before lockdown } \\
\text { learners difficult to fee } \\
\text { self-understanding }\end{array}$ & $\begin{array}{l}\text { Demonstrational } \\
\text { video of application, } \\
\text { self-doing exercise } \\
\text { through the } \\
\text { YouTube links, etc.. }\end{array}$ \\
\hline & & \multicolumn{2}{|c}{}
\end{tabular}

In current T-L pedagogy easy and flexible to deliver the course content to the learners through the online, the following Algorithm 2 described the OBE through the online learning.

\section{Algorithm 2: OBE through Teaching Learning Process in online platform.}

Step 1: Preparing the self-Instructional Material and posting in online platforms. Self-instructional material is in the form of Pdf, Video links, documents, prepared the simple and intelligible material [49].

Step 1a: Download the app from the App Store (iOS) or Google Play (Android). Learners can access the online materials through the mobile phone.

Step 1b: The course content also possible to learn without using the mobile data.

Step 1c: In online learning, the learner can enter his own login ID and password to visit the online class room session, and access the contents, assignments, quiz, etc. The following Figure 7 shows the dash board online platform.

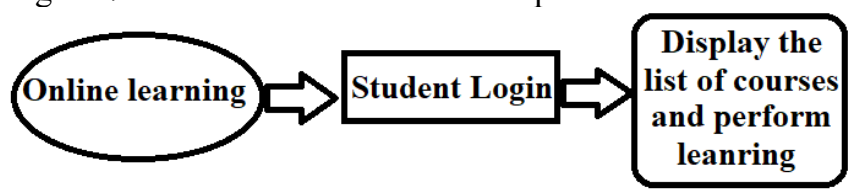

Figure 7. Access to learn online platforms.
Step 2: The teacher creates its own video lectures and selfinstructional material to the learners, the length of the each video contains 15 to 20 minutes of modules with rich content video display in a way all learners understand the concept. The learner can easily access the learning material as frequently as they want. The discussion forum started at the end of each module, the information can be saved for later reference and there is an opportunity to interact with the other learners [50].

Step 2a: Use the content of the course when offline

Step 2b: Instantly receive notifications, circulars, video links, etc...

Step 2c: Find the contact details of other students in the course.

Step 2d: Upload the course content, from mobile devices and view the course grade.

Step 3: The role of the teacher in the classroom describes the content of the video lecture in classroom and handling the tutorial session and explains briefly the practical implementation of Computer science subjects Blockchain technology, IoT, Cloud computing, C, C++, and JAVA etc... $[39,43,46,49,50]$. This practical knowledge is useful to the learners in their software field in near future.

Step 4: Starts the discussion forum after the lecture, create friendly environment for all the learners and discuss their opinions related to the topic.

Step 5: Create the virtual sessions and seminars on periodic basis to the learners to clear doubts on common topics.

Step 5a: Conduct one on one interaction makes, understand the concept learners' point of view and try elaborate the concept in the desired way.

Step 6: Provide the self-exercise, after completion of the live session, learners must practice the self exercises, learner can explore more on the topic and the concept becomes clearer, as per the Venn diagram as shown in Figure 8.

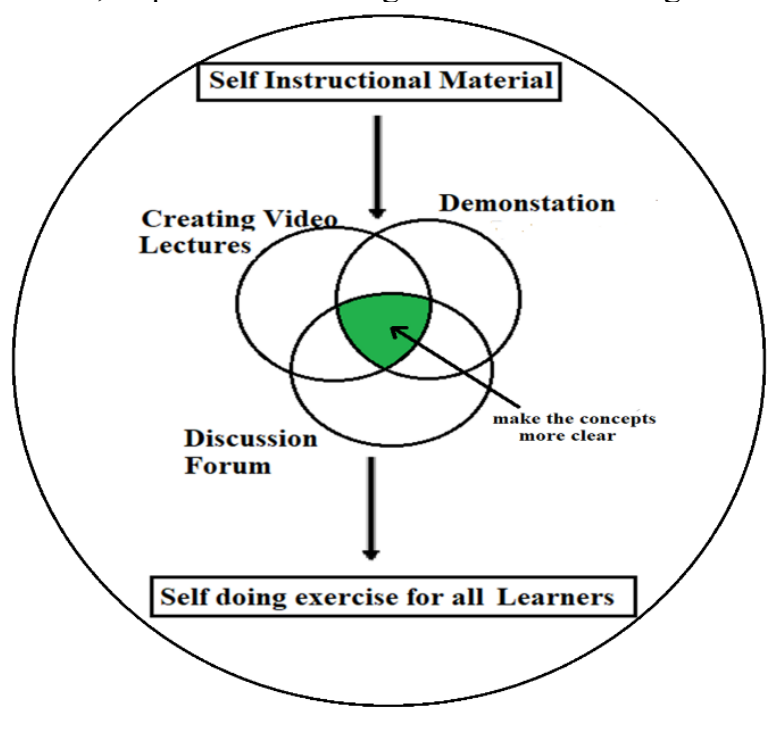

Figure 8. Layered architecture to achieve the OBE 
The left-hand side circle shows creating video lectures will generate general pedagogical knowledge. This refers to the length of the video which depends on course breakup, that organizes syllabus and assignments covers by the demonstration of the right side of the circle then start the discussion forum then learner makes the concepts clearer.

Step 7: Divide the entire course content into weekly/concept-wise content must be prepared into the video lecture uploaded into the module wise. OBE can be achieved through the online learning, it starts from top most layer, all learners can interact with the Moodle software. The next layer, learners watching the video lectures and teacher provide the demonstration to the corresponding lecture. The next layer conducting the assessments, the layered architecture of OBE as shown in Figure 9.

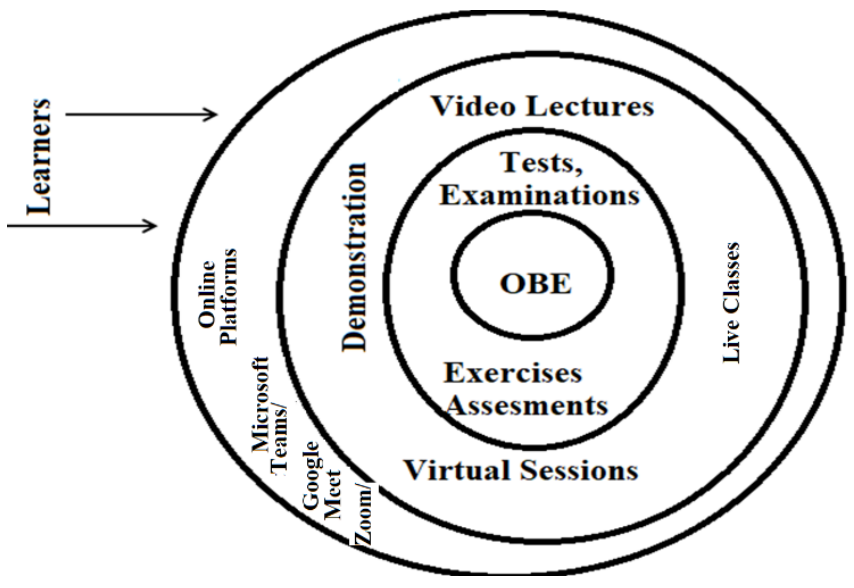

Figure 9. Layered architecture to achieve OBE

Step 8: Conduct the continuous assessment test for learners, that measures the learning performance of the learners, teachers prepared the course breakups. Course coordinator primarily set the question paper, who designs question paper templates, supervises question bank and question paper generation process.

Step 8a: Design the question paper templete, the coordinator decides maximum marks, sections, question group, marks for each question, question complexity, optional questions (if any), blooms for each question, Complexity of each Question and flag for Competitive Exam. As per the pyramid, the diagram is shown in Figure 10, assessment comes under the last stage, creation of video lectures is the first stage, then discussion forum is the second stage, remaining stages are assessment stages are very crucial stages for the leaners.

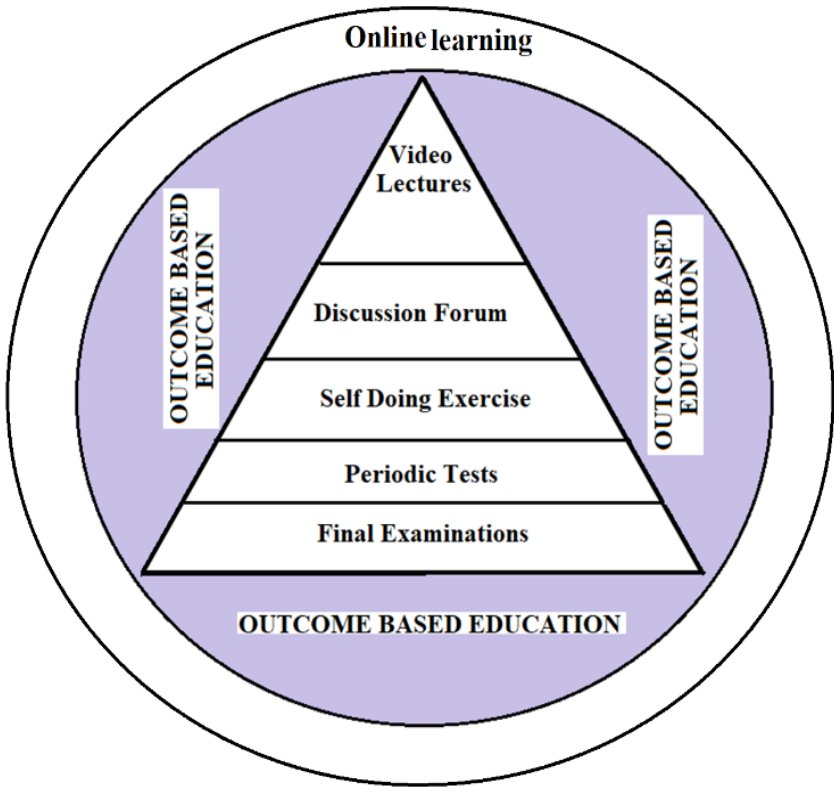

Figure 10. Online Learning Pyramid Architecture to achieve OBE

Step 9: The final assessment and grading decides by the Controller of Examinations $(\mathrm{CoE})$ and they verified course educational objective (CEO) achieved or not.

Step 9a: In online learning, prepared the video content, the content of the lecture video or PPTs have been released a day prior to the practical session or theoretical session, the learner goes through video after the lecture hours.

Step 9b: Starts the query session, the teachers encourage the learners to ask the questions and post the questions in the online platform. All posted questions are related to posted video and PPts. Not only teachers to answer all the queries through interactive sessions, but they are also encouraged to learners actively interact and sharing their opinions while answering the questions of other learners.

\section{Results and Discussions}

We implemented OBE through T-L process through online learning in.iOBE 5.2 software on MATLAB 2016b [18], it defines the course objectives, course outcome and program goals of the course, input submitted to the excel file, it contains the learner information and mapping the course outcomes to program goals [51]. The corresponding $\mathrm{CO}$ mapped to the 12 unique PO, the $\mathrm{CO}$ mapped to the corresponding PO and indicates as Low as ' 1 ', Medium as ' 2 ' and High as ' 3 ' as shown in Table 4 . 
Table 4. Input excel file for CO-PO mapping

\begin{tabular}{|c|c|c|c|c|c|c|c|c|c|c|c|c|c|}
\hline \multirow[b]{2}{*}{ PSO } & \multirow[b]{2}{*}{$\begin{array}{l}\text { Course } \\
\text { Objectives }\end{array}$} & \multicolumn{12}{|c|}{ PO's for Compiler Design } \\
\hline & & $\bar{o}$ & ญ̂ & $\hat{0}$ & $\stackrel{\Xi}{0}$ & $\stackrel{2}{\varrho}$ & $\stackrel{8}{2}$ & $\hat{0}$ & $\stackrel{\infty}{\stackrel{\infty}{0}}$ & ஓे & $\stackrel{0}{0}$ & $\overline{0}$ & $\stackrel{1}{0}$ \\
\hline \multirow{3}{*}{ 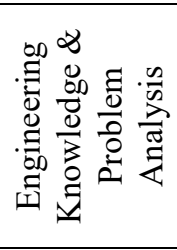 } & $\mathrm{CO} 1$ & 2 & & 3 & & & 3 & & & & & 1 & \\
\hline & $\mathrm{CO} 2$ & & 1 & & & 2 & & & 3 & & & & \\
\hline & $\mathrm{CO} 3$ & & & 3 & 1 & & & 2 & & & 1 & & \\
\hline \multirow{4}{*}{ 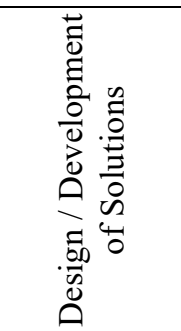 } & $\mathrm{CO} 1$ & 1 & & & & 2 & & & & 3 & & & \\
\hline & $\mathrm{CO} 2$ & & 2 & & 3 & & & 3 & & & & 2 & \\
\hline & CO3: & & & 3 & & & 2 & & & 1 & & & 2 \\
\hline & CO4: & 2 & & 1 & & & 3 & & 1 & & & & \\
\hline
\end{tabular}

The three taxonomies are Low $=1$ (knowledge-based goals), Medium=2 (skill-based goals), High $=3$ (affective goals). The course of 20 students and obtain the result of $\mathrm{CO}$ and PO mapping to generates the output graphs in MATLAB as follows.

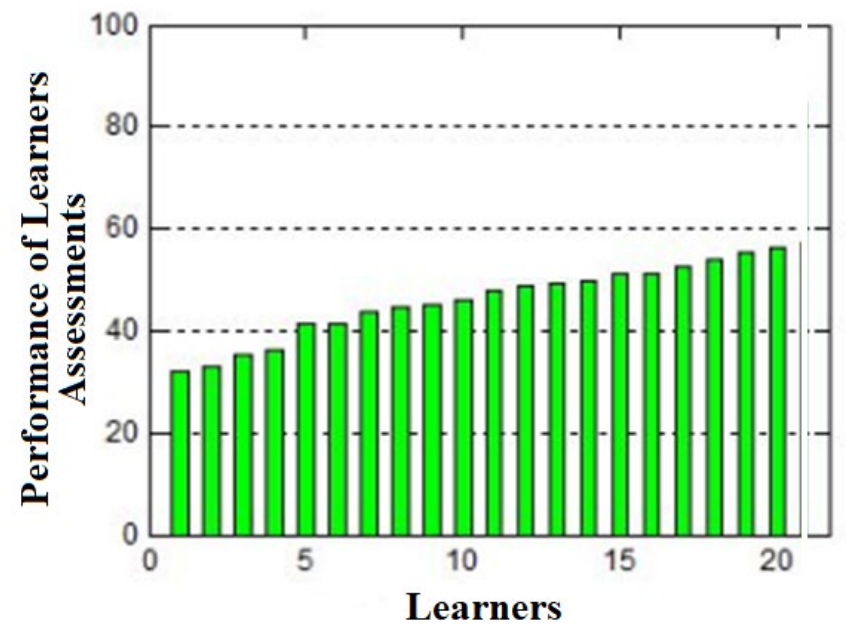

Figure 11. Performance of the learners

The iOBE 5.2 software run on MATLAB compiler, and it computes the learning objectives for each course and plotted the graphs. The corresponding CO and PO's are mapping to the percentage of CO-PO attainment as shown in Figure 12.

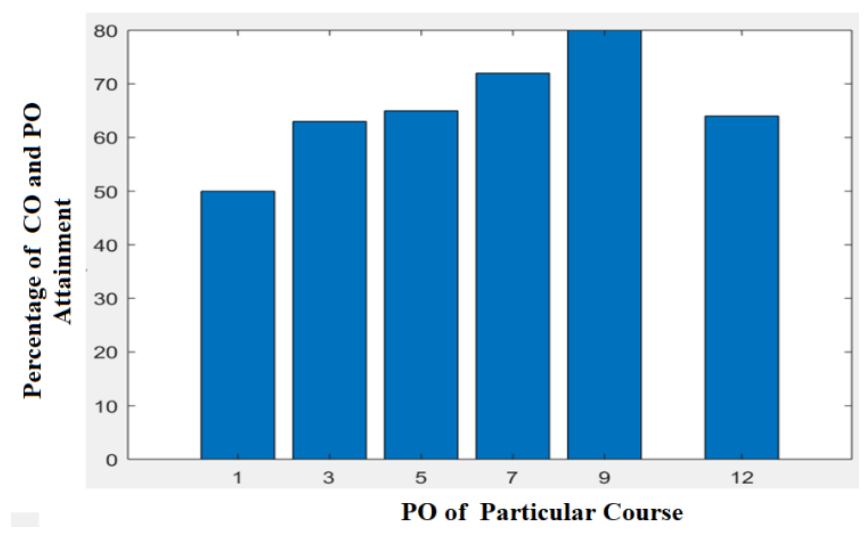

Figure 12. CO-PO mapping

It also calculates the learner performance and obtain each $\mathrm{CO}$ and map CO-PO to attain the percentage and performance of knowledge received by the learners gets evaluated through the attainment process. The corresponding performance of each student's CO's percentage of attainment are as defined as engineering knowledge and problem solving are shown in Figure 13. 


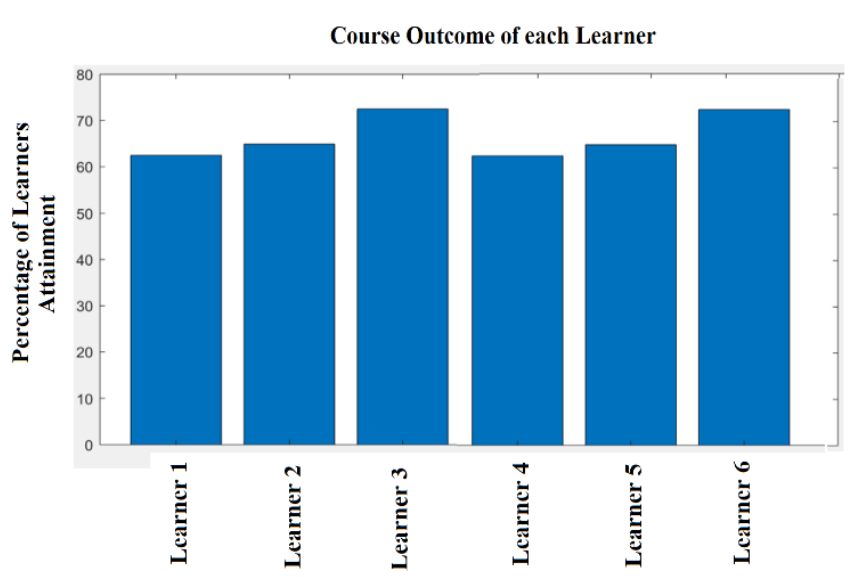

Figure 13. Each learner performance at end of the course

We conducted the survey on OBE through T-L process through online at the three institutions, indicated as institution $\mathrm{A}$, institution $\mathrm{B}$ and institution $\mathrm{C}$ as follows.

\section{Institution A:}

This institution offers its entire curriculum in OBE and offers different courses. In online learning platform this institution offers a smart board enable teaching and display presentations and monitoring the students. Conducting the assessments to students and provides the various relative grading system, it removed the attendance monitoring system during COVID19 lockdown. Every course responsibility to the course coordinator and he was updated to the course material.

\section{Table 6. Learners responses to the survey of institution $A$}

\begin{tabular}{|c|c|c|c|}
\hline \multirow{4}{*}{\begin{tabular}{l}
\multicolumn{1}{c}{ Survey Questions } \\
during COVID-19 \\
lockdown for E- \\
leanring
\end{tabular}} & \multirow{3}{*}{\multicolumn{2}{|c|}{\begin{tabular}{l}
\multicolumn{1}{c}{ Total } \\
Number \\
Students $=66$
\end{tabular}}} & \multirow[t]{4}{*}{ Outcome } \\
\hline & & & \\
\hline & & & \\
\hline & $\begin{array}{r}\text { Ma } \\
l e=39\end{array}$ & $\begin{array}{l}\text { Fe } \\
\text { male= } \\
27\end{array}$ & \\
\hline $\begin{array}{l}\text { User Devices are } \\
\text { most useful for E- } \\
\text { learning in Covid-19 }\end{array}$ & 32 & 26 & \begin{tabular}{l}
\multicolumn{2}{r}{ User devices } \\
are most \\
important for \\
online learning
\end{tabular} \\
\hline $\begin{array}{l}\text { Quality of service } \\
\text { is the most useful for } \\
\text { E-learning in Covid- } \\
19\end{array}$ & 35 & 23 & $\begin{array}{l}\text { Quality of } \\
\text { the service is } \\
\text { the most } \\
\text { essential for } \\
\text { online learning }\end{array}$ \\
\hline $\begin{array}{l}\quad \text { Accessing speed } \\
\text { is the most useful for } \\
\text { E-learning in } \\
\text { COVID-19 }\end{array}$ & 42 & 24 & \begin{tabular}{l}
\multicolumn{2}{c}{ Accessing } \\
speed is the \\
most essential
\end{tabular} \\
\hline
\end{tabular}

\begin{tabular}{|c|c|c|c|}
\hline & & & $\begin{array}{l}\text { for online } \\
\text { learning }\end{array}$ \\
\hline $\begin{array}{l}\text { During COVID- } \\
19 \text { lockdown, } \\
\text { prerecorded lectures } \\
\text { shared through } \\
\text { YouTube is useful } \\
\text { for E-learning }\end{array}$ & 51 & 4 & \begin{tabular}{l}
\multicolumn{2}{c}{ Prerecorded } \\
lectures are \\
most useful to \\
upload \\
YouTube
\end{tabular} \\
\hline $\begin{array}{l}\text { During COVID- } \\
19 \text { lockdown, } \\
\text { prerecorded lectures } \\
\text { shared through } \\
\text { Google Drive is } \\
\text { useful for E-learning }\end{array}$ & 48 & 12 & \begin{tabular}{l}
\multicolumn{2}{c}{ Prerecorded } \\
lectures are \\
most useful to \\
upload in \\
Google drive
\end{tabular} \\
\hline \begin{tabular}{lr}
\multicolumn{1}{c}{ During } & COVID- \\
19 & lockdown, \\
Google & slides \\
uploaded on the \\
faculty \\
websites
\end{tabular} & 49 & 13 & $\begin{array}{l}\text { Google } \\
\text { slides uploaded } \\
\text { on the faculty } \\
\text { official } \\
\text { websites are } \\
\text { most useful }\end{array}$ \\
\hline $\begin{array}{l}\text { Live lectures } \\
\text { using Zoom meeting } \\
\text { is preferable for } \\
\text { online education }\end{array}$ & 23 & 12 & \begin{tabular}{lr}
\multicolumn{1}{c}{ conduct } \\
online classes \\
through Zoom \\
meetings are \\
feasible
\end{tabular} \\
\hline $\begin{array}{l}\text { To conduct Zoom } \\
\text { meeting at least } \\
\text { thrice a weak }\end{array}$ & 34 & 15 & \multirow{3}{*}{$\begin{array}{l}\text { Zoom } \\
\text { meetings are } \\
\text { most useful to } \\
\text { conduct the } \\
\text { online classes }\end{array}$} \\
\hline $\begin{array}{l}\text { To conduct Zoom } \\
\text { meeting at least } \\
\text { twice a weak }\end{array}$ & 30 & 16 & \\
\hline $\begin{array}{l}\text { To conduct Zoom } \\
\text { meeting at least } \\
\text { twice a weak }\end{array}$ & 36 & 21 & \\
\hline
\end{tabular}

Table 6 provides the survey results during the COVID-19 lockdown, where a majority of students gave a positive response to online learning. Female students giving more positive responses compared to the male learners. Majority of learners provides importance to the electronic gadgets and they are addicted, quality of teaching is the most essential thing in online teaching, accessing speed if internet is the most crucial thing.

\section{Institution B:}

This institution receives funding from MHRD India, it is an engineering university for undergraduates and offers various programs. All teachers follow the unique platform while teaching and unique format of teachers presentations while teaching online classes. All messages related to the online classes were sent through WhatsApp. This institution has adopted to use Microsoft Teams as online T-L platform. The following Table 7 shows the survey of 167 teachers, this survey proved that, the teachers workload becomes thrice in the COVID-19 lockdown, teachers prepared the online material, and conduct the live classes and upload the recorded class link in YouTube, the teachers responses of the survey as shown in the Table 7. 
Table 7. Teachers responses to the survey of institution B

\begin{tabular}{|l|l|l|l|l|}
\hline Survey Question & \multicolumn{2}{l|}{$\begin{array}{l}\text { Before } \\
\text { COVID-19 }\end{array}$} & \multicolumn{2}{l|}{ After COVID-19 } \\
\hline \multicolumn{2}{|c|}{ Total teachers 167 } & $\begin{array}{l}\text { OUT } \\
\text { COM } \\
\text { E }\end{array}$ & & $\begin{array}{l}\text { OUTCO } \\
\text { ME }\end{array}$ \\
\hline $\begin{array}{l}\text { Every course } \\
\text { learning } \begin{array}{c}\text { material } \\
\text { prepared the } \\
\text { teacher }\end{array}\end{array}$ & No & 121 & YES \\
\hline $\begin{array}{l}\text { Video materials } \\
\text { prepared by the } \\
\text { teacher }\end{array}$ & 35 & No & 134 & YES \\
\hline $\begin{array}{l}\text { Demonstrational } \\
\text { Videos }\end{array}$ & 15 & No & 145 & YES \\
\hline Discussion Forum & 10 & No & 153 & YES \\
\hline Virtual Sessions & 15 & No & 148 & YES \\
\hline Self-Assessments & 23 & No & 146 & YES \\
\hline $\begin{array}{l}\text { Concept wise course } \\
\text { material }\end{array}$ & 16 & No & 149 & YES \\
\hline Periodic test & 28 & No & 142 & YES \\
\hline Final Examination & 14 & No & 151 & YES \\
\hline
\end{tabular}

In Table 7, provides the teachers are interested while taking the classes and most of the teachers are posted course material, video materials and started the discussion forum and most of the learners are adopted to online learning.

\section{Institution C:}

This institution uses the Google Meets platform for online learning, they provide video links to students allowing them to listen to lectures at any time. Teachers are more interactive with the students to present the ppts and play the videos. The following Table 8 provides the student responses on online platforms.

Table 8. Learner responses on online platforms.

\begin{tabular}{|c|c|c|}
\hline Survey Question & \multicolumn{2}{|c|}{$\begin{array}{c}\text { Total Number of Students =66 } \\
\text { (out of 10) }\end{array}$} \\
\cline { 2 - 3 } & $\begin{array}{l}\text { Number of } \\
\text { Males= 39 } \\
\text { (Out of 10) }\end{array}$ & $\begin{array}{l}\text { Number } \\
\text { Females=27 } \\
\text { (Out of 10) }\end{array}$ \\
\hline $\begin{array}{l}\text { Google } \\
\text { Classroom, teams, } \\
\text { Microsoft team } \\
\begin{array}{l}\text { Zoom tools used to } \\
\text { teach online classes }\end{array}\end{array}$ & 8.9 & 9.5 \\
\hline $\begin{array}{c}\text { Accessing of the } \\
\text { learning material in } \\
\text { Google class room, }\end{array}$ & 7.6 & \\
\hline
\end{tabular}

\begin{tabular}{|l|l|l|}
\hline $\begin{array}{l}\text { Microsoft Teams, } \\
\text { and zoom }\end{array}$ & \\
\hline $\begin{array}{l}\text { Satisfaction of } \\
\text { students during } \\
\text { COVID-19 } \\
\text { lockdown }\end{array}$ & 8.5 & 7.5 \\
\hline $\begin{array}{l}\text { Accessing of } \\
\text { Microsoft Teams, } \\
\text { Google class room } \\
\text { and Zoom instead of } \\
\text { using rather than } \\
\text { mobile }\end{array}$ & 6.8 & \\
\hline $\begin{array}{l}\text { Submission of } \\
\text { assignment in } \\
\text { Google class, } \\
\text { Microsoft teams and } \\
\text { zoom }\end{array}$ & & \\
\hline $\begin{array}{l}\text { Submission of } \\
\text { quizzes ras } \\
\text { convenient to answer }\end{array}$ & 8.1 & 7.6 \\
\hline \multicolumn{2}{|l|}{} & \\
\hline
\end{tabular}

In Table 8, provides the survey gives the rate of factor out of 10 , as per the survey provides that, most of the learners adopted to the online learning, accessing the online materials, self-study, submission of assignments and quizzes.

\section{Conclusions}

This study provides recommendations to achieve OBE during the COVID-19 lockdown, and analyses the impact of online education through online platforms like Microsoft Teams, Google Meets, and Zoom, including the health-related issues of learners and teachers from online learning during COVID19 pandemic. As per the survey learners are adopted the online platforms and T-L process established between the leaners and teachers, in this paper discovered the 3 educational institutions survey, all three institutions learners are satisfactory with the online learning but they are facing health problems, institution A leaners identified that 35\% (obtained percentage value, learners' positive rate (x) and negative rate $(\mathrm{y})$ divides by total number of learners $(\mathrm{N})$, then obtained percentage $\left.=\frac{x-y}{N} \times 100\right)$ were not satisfied with online learning, institution-B learners $68 \%$ were adopted the class room based daily learning, institution-C learners $75 \%$ adopted to the online learning, self-study, YouTube links. There were a very few learners in the 'disagree' category. Among three institution students adopted online learning using Microsoft Teams, Google Meets platform during COVID-19 pandemic.

The result section proved that CO-PO mapping and attainments used in iOBE5.2 software provides effective and efficient T-L process. This study recommended online leaning and expressed high level of satisfaction on the part of the students. According to the three-institution survey implemented OBE through T-L process for online learning. 
In the future, some more T-L tools are released in COVID-19 pandemic, the skills of learners with new pedagogical principles would definitely be improved with the real-time demand. During lockdown students were shown to be efficient in accessing and using the internet to improve their knowledge.

The learner choice should be implemented in online platforms, in-depth of the learner behaviour and learner

\section{Acknowledgements.}

I humbly like to thank the respected honourable chancellor Sunil Galgotia, Galgotias University India, and respected CEO Dhruv Galgotia for providing to create health environment for successfully implemented of OBE in Galgotias University. I convey my gratitude to Vice-Chancellor, Pro-Vice Chancellor, Dean School of Computing Science and Engineering, Programme chairs, committee members who supported with love and understanding. They provided their most valuable time, patient guidance and advise throughout this work, without their cooperation and contribution, this study could not have been undertaken. I would like to acknowledge everyone who was a part of Galgotias University and my dear colleagues and my students for their continuous support to complete this work.

\section{References}

[1] Passey D. Computer science (CS) in the compulsory education curriculum: Implications for future research. Education and Information Technologies. 2017 Mar $1 ; 22(2): 421-43$.

[2] Nassr RM, Aborujilah A, Aldossary DA, Aldossary AA. Understanding education difficulty during COVID-19 lockdown: Reports on malaysian university Students' experience. IEEE Access. 2020 Oct 12;8:186939-50.

[3] Nugroho RA, Basari A, Suryaningtyas VW, Cahyono SP. University students' perception of online learning in Covid19 pandemic: A case study in a translation course. In2020 International Seminar on Application for Technology of Information and Communication (iSemantic) 2020 Sep 19 (pp. 225-231). IEEE.

[4] Bottino RM, Artigue M, Noss R. Building European collaboration in technology-enhanced learning in mathematics. InTechnology-Enhanced Learning 2009 (pp. 73-87). Springer, Dordrecht.

[5] Barros C, Carvalho AA, Salgueiro A. The effect of the serious game Tempoly on learning arithmetic polynomial operations. Education and Information Technologies. 2020 May;25(3):1497-509.

[6] Pratama UN, Surahman E. Investigating Student Responses of Online Learning during the Covid-19 Pandemic in Performing Art Education. In2020 6th International Conference on Education and Technology (ICET) 2020 Oct 17 (pp. 64-69). IEEE.

[7] Khan MA, Nabi MK, Khojah M, Tahir M. Students' perception towards e-learning during COVID-19 pandemic in India: An empirical study. Sustainability. 2021 Jan;13(1):57.

[8] Han Z, Wei B, Hong Y, Li T, Cong J, Zhu X, Wei H, Zhang W. Accurate screening of COVID-19 using attention-based deep 3D multiple instance learning. IEEE transactions on medical imaging. 2020 May 21;39(8):2584-94.

[9] Demuyakor J. Coronavirus (COVID-19) and online learning in higher institutions of education: A survey of the perceptions of Ghanaian international students in China. flexibility should be needed in online learning platforms and improve the health conditions of online learners.

Online Journal of Communication and Media Technologies. 2020 May 19;10(3):e202018.

[10] Khattar A, Jain PR, Quadri SM. Effects of the disastrous pandemic COVID 19 on learning styles, activities and mental health of young Indian students-a machine learning approach. In2020 4th International Conference on Intelligent Computing and Control Systems (ICICCS) 2020 May 13 (pp. 1190-1195). IEEE.

[11] Jiang H, Islam AA, Gu X, Spector JM. Online learning satisfaction in higher education during the COVID-19 pandemic: A regional comparison between Eastern and Western Chinese universities. Education and Information Technologies. 2021 Mar 31:1-23.

[12] Duong V, Luo J, Pham P, Yang T, Wang Y. The ivory tower lost: How college students respond differently than the general public to the covid-19 pandemic. In2020 IEEE/ACM International Conference on Advances in Social Networks Analysis and Mining (ASONAM) 2020 Dec 7 (pp. 126-130). IEEE.

[13] Bączek M, Zagańczyk-Bączek M, Szpringer M, Jaroszyński A, Wożakowska-Kapłon B. Students' perception of online learning during the COVID-19 pandemic: a survey study of Polish medical students. Medicine. 2021 Feb 19;100(7).

[14] Muthuprasad T, Aiswarya S, Aditya KS, Jha GK. Students' perception and preference for online education in India during COVID-19 pandemic. Social Sciences \& Humanities Open. 2021 Jan 1;3(1):100101.

[15] Dias SB, Hadjileontiadou SJ, Diniz J, Hadjileontiadis LJ. DeepLMS: a deep learning predictive model for supporting online learning in the Covid-19 era. Scientific reports. 2020 Nov 16;10(1):1-7.

[16] Abbasi S, Ayoob T, Malik A, Memon SI. Perceptions of students regarding E-learning during Covid-19 at a private medical college. Pakistan Journal of Medical Sciences. 2020 May;36(COVID19-S4):S57.

[17] Chung E, Subramaniam G, Dass LC. Online learning readiness among university students in Malaysia amidst COVID-19. Asian Journal of University Education. 2020 Jul;16(2):46-58.

[18] Mallikarjuna B, Dayananda P, Niranjanamurthy M, Kumar $\mathrm{P}$, Sabharwal M. OUTCOME-BASED EDUCATION FOR COMPUTER SCIENCE IN E-LEARNING THROUGH MOODLE. PalArch's Journal of Archaeology of Egypt/Egyptology. 2020 Nov 2;17(9):8740-52..

[19] Molnár G, Námesztovszki Z, Glušac D, Karuović D, Major L. Solutions, experiences in online education in Hungary and Serbia related to the situation caused by Covid- 19 . In2020 11th IEEE International Conference on Cognitive Infocommunications (CogInfoCom) 2020 Sep 23 (pp. 000601-000606). IEEE.

[20] Almazova N, Krylova E, Rubtsova A, Odinokaya M. Challenges and opportunities for Russian higher education amid COVID-19: Teachers' perspective. Education Sciences. 2020 Dec;10(12):368.

[21] Tang T, Abuhmaid AM, Olaimat M, Oudat DM, Aldhaeebi M, Bamanger E. Efficiency of flipped classroom with 
online-based teaching under COVID-19. Interactive Learning Environments. 2020 Sep 11:1-2.

[22] Triatmojo W, Priyadi M. Implementation of Flipped Classroom on Experiences in Online Learning During Pandemic Covid-19 for a Project-Base Vocational Learning Guide. InJournal of Physics: Conference Series 2021 Mar 1 (Vol. 1842, No. 1, p. 012019). IOP Publishing.

[23] Oh Y, Park S, Ye JC. Deep learning covid-19 features on cxr using limited training data sets. IEEE transactions on medical imaging. 2020 May 8;39(8):2688-700.

[24] Alqahtani AY, Rajkhan AA. E-learning critical success factors during the covid-19 pandemic: A comprehensive analysis of e-learning managerial perspectives. Education sciences. 2020 Sep;10(9):216.

[25] Sakti RH, Sukardi S. Empirical Study of Flipped Classroom-Based E-Learning to Face Learning on Covid19 Pandemic: Empirical Effect. Jurnal Pendidikan dan Pengajaran. 2021 Apr 9;54(1).

[26] Campillo-Ferrer JM, Miralles-Martínez P. Effectiveness of the flipped classroom model on students' self-reported motivation and learning during the COVID-19 pandemic. Humanities and Social Sciences Communications. $2021 \mathrm{Jul}$ 20;8(1):1-9.

[27] Haqiyah A. Flipped classroom model integrated with the online learning platform and video biomechanic analysis to enhance learning outcome of Pencak silat during the Covid19 pandemic. Turkish Journal of Computer and Mathematics Education (TURCOMAT). 2021 May 13;12(11):2267-72.

[28] Hossain MS, Muhammad G, Guizani N. Explainable AI and mass surveillance system-based healthcare framework to combat COVID-I9 like pandemics. IEEE Network. 2020 Jul 8;34(4):126-32.

[29] Mallikarjuna B, Munish Sabharwal2Dayananda $P$, Niranjanamurthy $M$. THE CONSEQUENCES OF ELEARNING WITH COVID-19 PANDEMIC TO ACHIEVE OBE. PalArch's Journal of Archaeology of Egypt/Egyptology. 2020 Nov 2;17(9):8753-8.

[30] Guraya S. Combating the COVID-19 outbreak with a technology-driven e-flipped classroom model of educational transformation. Journal of Taibah University Medical Sciences. 2020 Aug;15(4):253.

[31] Mallikarjuna B, Sathish K, Krishna PV, Viswanathan R. The effective SVM-based binary prediction of ground water table. Evolutionary Intelligence. 2021 Jun;14(2):779-87.

[32] Satyawan IM, Wahjoedi W, Swadesi IK. The Effectiveness of Online Learning Through Undiksha E-Learning During the Covid-19 Pandemic. Journal of Education Technology. 2021 Jun 20;5(2):191-9.

[33] Hu S, Gao Y, Niu Z, Jiang Y, Li L, Xiao X, Wang M, Fang EF, Menpes-Smith W, Xia J, Ye H. Weakly supervised deep learning for covid-19 infection detection and classification from ct images. IEEE Access. 2020 Jun 29;8:118869-83.

[34] Mallikarjuna B, Viswanathan R, Naib BB. Feedback-based gait identification using deep neural network classification. J Crit Rev. 2019;7(4):2020.

[35] Baber H. Determinants of students' perceived learning outcome and satisfaction in online learning during the pandemic of COVID-19. Journal of Education and eLearning Research. 2020 Aug 23;7(3):285-92.

[36] Mallikarjuna B, Shrivastava G, Sharma M. Blockchain technology: A DNN token-based approach in healthcare and COVID-19 to generate extracted data. Expert Systems. 2021:e12778.

[37] Naji KK, Du X, Tarlochan F, Ebead U, Hasan MA, Al-Ali AK. Engineering Students' Readiness to Transition to
Emergency Online Learning in Response to COVID-19: Case of Qatar. EURASIA Journal of Mathematics, Science and Technology Education. 2020;16(10).

[38] Song Y, Zheng S, Li L, Zhang X, Zhang X, Huang Z, Chen J, Wang R, Zhao H, Zha Y, Shen J. Deep learning enables accurate diagnosis of novel coronavirus (COVID-19) with CT images. IEEE/ACM Transactions on Computational Biology and Bioinformatics. 2021 Mar 11.

[39] Mallikarjuna B, Reddy DA, Sailaja G. Enhancement of Railway Reservation System Using Internet of Things. InProceedings of the 1st International Conference Universal Computing, Communication in Data Engineering (CCODE2018) 2018.

[40] Khalil R, Mansour AE, Fadda WA, Almisnid K, Aldamegh M, Al-Nafeesah A, Alkhalifah A, Al-Wutayd O. The sudden transition to synchronized online learning during the COVID-19 pandemic in Saudi Arabia: a qualitative study exploring medical students' perspectives. BMC medical education. 2020 Dec;20(1):1-0.

[41] Mallikarjuna B, Reddy DA. Healthcare application development in mobile and cloud environments. InInternet of Things and Personalized Healthcare Systems 2019 (pp. 93-103). Springer, Singapore.

[42] Mulenga EM, Marbán JM. Prospective teachers' online learning mathematics activities in the age of COVID-19: A cluster analysis approach. EURASIA Journal of Mathematics, Science and Technology Education. 2020 Jun 15;16(9):em1872.

[43] Mallikarjuna B, Chakradhar P, Gadila SR. The role of emerging technologies in Internet of Things. InProc. Int. Conf. Comput., Commun. Data Eng.(CCODE) 2018 (pp. 1$6)$.

[44] Chen T, Peng L, Yin X, Rong J, Yang J, Cong G. Analysis of user satisfaction with online education platforms in China during the COVID-19 pandemic. InHealthcare 2020 Sep (Vol. 8, No. 3, p. 200). Multidisciplinary Digital Publishing Institute.

[45] Al-Kumaim NH, Alhazmi AK, Mohammed F, Gazem NA, Shabbir MS, Fazea Y. Exploring the impact of the COVID19 pandemic on university students' learning life: An integrated conceptual motivational model for sustainable and healthy online learning. Sustainability. 2021 Jan;13(5):2546.

[46] Mallikarjuna B. Feedback-based fuzzy resource management in IoT-based-cloud. International Journal of Fog Computing (IJFC). 2020 Jan 1;3(1):1-21.

[47] Mooney C, Becker BA. Investigating the impact of the COVID-19 pandemic on computing students' sense of belonging. ACM Inroads. 2021 May 10;12(2):38-45.

[48] Nasution AK, Ahmad NQ. Student Perceptions of Online Learning During the Covid-19 Pandemic. Jurnal As-Salam. 2020 Dec 12;4(2):195-204.

[49] Mallikarjuna B. Feedback-Based Resource Utilization for Smart Home Automation in Fog Assistance IoT-Based Cloud. International Journal of Fog Computing (IJFC). 2020 Jan 1;3(1):41-63.

[50] Basetty M, Ramanaiah KV, Mohanaiah P, Reddy VV. Recognizing Human-Object Using Genetic Algorithm for Face Detection in Natural Driving Environment. iManager's Journal on Software Engineering. 2012 Oct $1 ; 7(2): 10$.

[51] Mohamed-Kassim Z, Kamaruddin N. Towards an Efficient iCGPA System Using iOBE. In2017 7th World Engineering Education Forum (WEEF) 2017 Nov 13 (pp. 103-109). IEEE. 